\title{
The state of business incubation in the Northern Cape: A service spectrum perspective
}

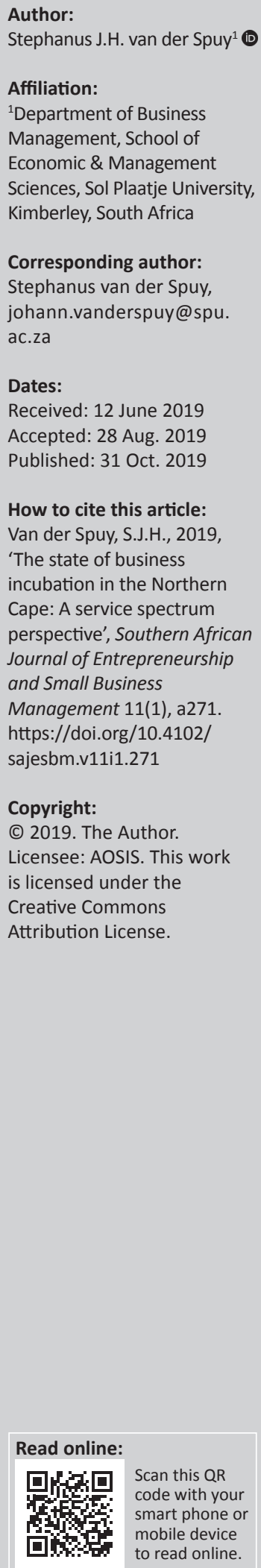

Background: Business incubation has the purpose of recruiting weak yet promising tenantentrepreneurs or incubates. The weaknesses may include a lack of skills and abilities, lack of resources or lack of knowledge. The business case or opportunity should be promising. Further to the purpose, business incubators attempt to turn these deficient businesses into sustainable entities that can exit or graduate the incubator and survive on their own devices. Without this intervention through the incubator, it is extremely unlikely that these tenant-entrepreneurs or incubates will survive. In order to achieve the maximum likelihood of successful graduateentrepreneurs and sustainable start-ups, business incubators must offer a full spectrum of services. These services should include access to physical premises, communal equipment, administrative support, training for skills development, access to professional and specialised skills, access to financial support, access to networking and access to mentorship.

Objectives: It is the purpose of this study, firstly, to investigate and determine which of these services business incubators within the Northern Cape Province of South Africa offer. Secondly, it is the further purpose of this study to benchmark the incubators within the Northern Cape Province to international best practice models.

Method: A qualitative research methodology was employed in this study. Data were collected through semi-structured interviews, transcribed and analysed through qualitative software. The sample consisted of 63 respondents from 7 business incubators within the province. The sampling method was purposive.

Results: The research results obtained indicated that four incubators within the province boast a very weak service offering. Furthermore, only one incubator truly benchmarked competitively against international best practice models.

Conclusion: The study provides recommendation with regards to specialist mentoring, skills development and training of entrepreneurs and incubation-practitioners, as well as access to funding and physical upgrades of incubators. The research contributes to a very sparse body of existing research on small, medium and micro-enterprise (SMME) development within the Northern Cape Province. The study provides future research questions for academic researchers.

Keywords: Entrepreneurship; business incubator; business incubation; business incubator models; business incubator generations; business incubator services; entrepreneur support; start-up support.

\section{Introduction}

South Africa is facing an entrepreneurial and unemployment crisis with an official unemployment rate estimated between $25 \%$ and $28 \%$, and an unofficial unemployment rate of $37 \%$ (Du Toit et al. 2018:122; Lilenstein, Woolard \& Leibbrandt 2018:2; Littlewood \& Holt 2018:526; Mahadea \& Kaseeram 2018:3). The impact of this crisis is magnified in the Northern Cape Province of South Africa (Fransman \& Yu 2018:5). This arid province is the largest province in the country and is rural with vast spatial complexities (Badenhorst et al. 2018:917; Biyase \& Zwane 2018:10). This study conducts an assessment of the quality of business incubators within the province and draws conclusions on how to improve the quality of business incubation within the province.

This study is useful not only in a rural South African context but also to other emerging markets that are rural and spatially complex.

Business incubators are important for small, medium and micro-enterprise (SMME) development in an economy, because they assist with and accelerate the start-up, development and growth of SMMEs (Guerrero et al. 2018:151; Li, Ur Rehman \& Asim 2019:2; Mahmood et al. 2016:311; Sagath 
et al. 2019:3). They do so with the hope that incubates will graduate from the incubator, in charge of sustainable and profitable business ventures (Bose \& Goyal 2018:353; Bruneel et al. 2012:110; Olkiewicz et al. 2019:1; Wolniak \& Grebski 2018:39). Incubators must provide regional economic development in the geographical demarcations within which they are mandated to operate (Bank, Fichter \& Klofsten 2016:2; Lamine et al. 2018:1121; Miranda \& Borges 2019:37; Sudana et al. 2019:3; Xiao \& North 2018:29). Regional economic development entails a growth in the gross-domestic product, income levels, capital investment, innovations, education, trade of products and services of greater quality, production of environmental solutions, presence of SMMEs, formal employment and greater economic participation by regional citizens (Bailey 2019:21; Beer et al. 2019:172; Beugelsdijk, Klasing \& Milionis 2019:155; Faber \& Gaubert 2019:2245; Yakubova \& Moustoifa 2019:45; Zheng et al. 2019:25). This economic development is achieved when the incubator provides the incubates with access to services that protect them from the liability of smallness, the liability of newness, resource deficit and some entrepreneurial risk in order to enhance their chances of survival and success (Ahmad 2014:375; Bollingtoft 2012:304; DeVaughn \& Leary 2018:2; Njau, Wachira \& Mwenda 2019b:36; Wenner et al. 2018:4).

Business incubator services include business skills development training, technical services, business mentoring and coaching, business and marketing plan development services, access to specialised services such as legal, marketing and financial services, management team development services, shared office or manufacturing space, shared equipment, access to administrative support, networking services and access to financial products (Albort-Morant \& Oghazi 2016:2126; Bollingtoft 2012:304; Godeiro et al. 2018:9; Ikebuaku \& Dinabo 2018:10; Lamine et al. 2018:1124; Njau, Mwenda \& Wachira 2019a:18 by Allahar \& Brathwaite 2016:6; Perdomo, Alvarez \& Urbano 2014:40; Tello, Yang \& Latham 2012:375; Torun 2016:6). The essential business incubator services can be packaged into the following five categories (Bakkali, Messeghem \& Sammut 2014:1; Battisstella, De Toni \& Pessot 2018:5):

- Category 1: Access to physical resources such as equipment, machinery and office or manufacturing space.

- Category 2: Access to secretarial and administrative support.

- Category 3: Access to financial resources, be it by means of direct investment or linking incubates with potential investors and funders.

- Category 4: Access to start-up assistance such as training for skills development, access to specialised skills, mentorship and coaching.

- Category 5: Access to business networks.

Mention must be made of virtual incubators, also called incubators without walls, which are a type of incubator that incubates selected incubates electronically and online via virtual mentorship, virtual network linkages, online service delivery, online training, virtual resource linkages and investment without anchoring the incubates within a physical incubator nestled in a specific geographical location. This allows the virtual incubator to incubate target entrepreneurs that are promising regardless of their physical proximity or location and also greatly reduces the overhead expenses related to the provision of physical premises and physical support related with the physical layout of a physical incubator (Aernoudt 2004:132; Carayannis \& Von Zedwitz 2005:103; Isabelle 2013:21; Nicolopoulou et al. 2017:22; Von Zedwitz 2003:190). It must be noted thus that virtual incubators are deliberately distancing themselves from physical services and cannot be critiqued for the absence of such (Bruneel et al. 2012:120). Thus, virtual incubators should not be viewed negatively for not providing access to physical premises as well as equipment.

Whilst researching this article, it proved difficult to find academic research on SMMEs within the province. However, a recent study found the most significant challenges Northern Cape-based SMMEs face are poor location, lack of access to information on available financial offerings, inability to make informed business decisions, lack of business and finance skills, lack of access to appropriate technology, lack of support to find financial loans and grants, lack of business networks and lack of access to a suitable workforce (Babalola \& Agbenyegah 2016:1757). A regional incubator with a decent spectrum of services should be able to bridge and solve the above-mentioned problems.

The Northern Cape is a vast and arid province within the Republic of South Africa (RSA) covered by mostly desert (Mokwena 2018:16). It is bordered by Namibia and Botswana to the north. The Kalahari and Great Karoo deserts cover most of the province (Mthombeni 2019:10). Distances between towns, places of significance,

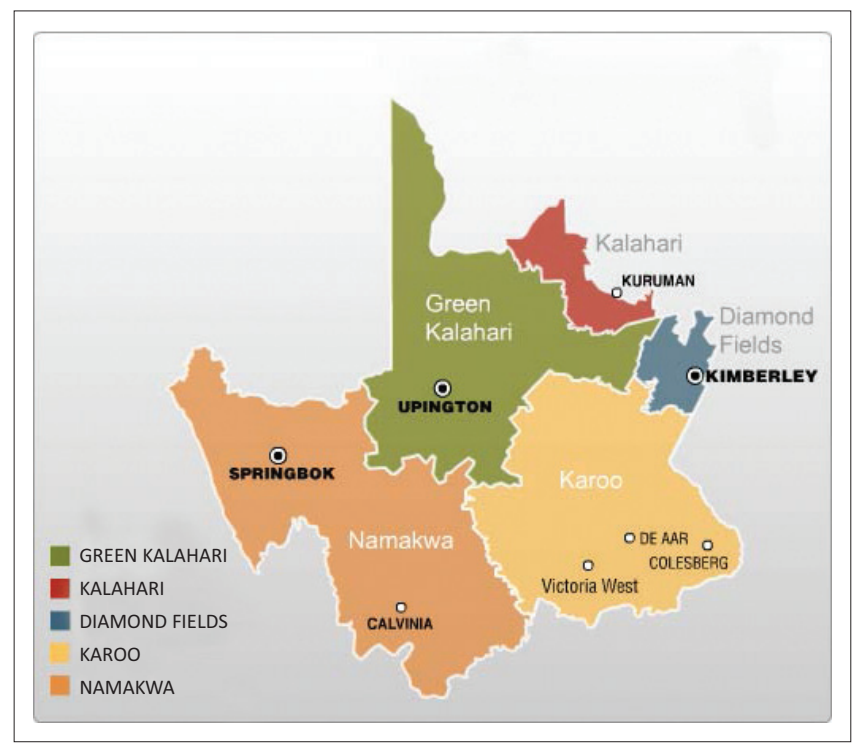

Source: FindTripInfo.co.za, 2014, A travel guide to the countries of Africa compiled by local destination specialists, Map of the Northern Cape, viewed 25 August 2019, from http:// www.findtripinfo.com/south-africa/northern-cape/diamond-fields.html

FIGURE 1: Map of the Northern Cape with major centres of commerce and arid biospheres. 
commercial centres and markets are great (Jacobs, Du Preez \& Fairer-Wessels 2019a:3).

The Northern Cape occupies 30\% of South Africa's land mass and has the smallest economy and population, approximately 1200000 persons, in the RSA (Statistics South Africa 2016; Young 2017:1).

The Northern Cape has a high unemployment rate, with almost half of its employable population being unemployed, approximately 219000 persons (Statistics South Africa 2016). The Northern Cape does offer potential business opportunities to SMMEs in the eco-tourism, stargazing, arid-agriculture, mining and minerals, and renewable energy sectors (Jacobs et al. 2019:3). This research will aid on how effective regional business incubators within the province are in assisting SMMEs to start up and contribute to poverty and unemployment alleviation by ensuring that sustainable ventures graduate from the incubator (Beangstrom 2017:1, 2018:1).

The research problem has thus been formulated as follows:

After reading the research conducted by Lose, Nxopo, Maziriri and Madinga (2016:133) as well as Masutha and Rogerson (2014:52) which touched on Northern Cape incubators. It remains unknown whether the existing services spectrum offered by Northern Cape regional incubators are sufficient to meet business incubators best practice standards, needed to create self-sustainable business ventures that can graduate the incubator and contribute to economic development.

As the province is currently largely dependent on mining activities for employment creation, this research conducted can be considered very important from a local government perspective, as the Northern Cape provincial government in 2016 announced that the Northern Cape economy should be diversified into the SMME sector, as well as renewable energy sector to reduce the overdependence on the mining sector exclusively as employment and wealth creator (Ahmed 2017:1; Young 2017).

The purpose of this study is to investigate the current spectrum of business incubation services that regional incubators in the Northern Cape offer and compare it with best practice incubator models'. The study was undertaken at the large publically funded business incubators within the Northern Cape, as well as the very few private incubators that exist within this vast province of the RSA.

The following research questions guided the study:

- What spectrum of services do regional incubators in the Northern Cape offer incubates?

- How does the spectrum of services of Northern Cape regional incubators relate to business incubator best practice models?

The study contributed on multiple levels. Firstly, it contributed to academia, as there is extremely limited research that has been conducted on Northern Cape-based SMMEs, as well as regional business incubators.

At least on theoretical level, this study provided insights on the standards and quality of business incubation in the province. Secondly, this study also contributed to the policymakers and industry practitioners. It pinpointed the strengths and weaknesses in the province to practitioners and policymakers. These individuals may find the findings very useful to address shortcomings in their respective service spectrums or the way they manage their incubators and incubates.

\section{Literature review}

According to the World Bank's Information for Development (InfoDev 2014:8) programme, business incubation can be defined as a process supporting the creation, development of sustainable ventures and the scaling of growth-orientated early-stage ventures (Hausberg \& Korreck 2018:10; Kapinga et al. 2018:3; Lamine et al. 2018:1123; Nair \& Blomquist 2018:9, 2019:273; Olkiewicz et al. 2019:3; Sudana et al. 2019:5; Van Weele et al. 2019:2). The business incubator provides the entrepreneur with an enabling environment that is conducive for the start-up and development of the venture. The environment within the business incubator is considered enabling because it should reduce the cost of start-up, increase the confidence and business skills of the entrepreneur, and connect the entrepreneur with resources needed to start and grow the business (Battisella et al. 2018:4; Gozali et al. 2018:1058; Ikebuaku \& Dinabo 2018:18; InfoDev 2014:8; Mansoori, Karlsson \& Lundqvist 2019:4; Njau et al. 2019:38; Olokundun et al. 2019:2; Sanyal \& Hisam 2018:62; Van Weele et al. 2018:1162). It is furthermore noted that business incubators are tasked with the purpose of accelerating and expediting the start-up process of new ventures within the business incubator programme as opposed to a slower and delayed start-up process outside the business incubator programme (Caetano, Preto \& Amaral 2019:223; Dvouletý et al. 2018:556; Famiola \& Hartati 2019:57; Honig \& Karlsson 2010:719; Kepenek \& Eser 2019:1; McDonald-Junor, Rossiter \& Smith 2018:2; Rosa, Sukoharsono \& Saraswati 2019:70; Torun et al. 2018:92).

Romein and Trip (2017:440) define a business incubator as a dedicated space and supportive environment for start-up companies to be created, nurtured so that they can survive their infancy, when they are particularly vulnerable, grow and become self-sustainable business ventures that can survive on their own outside the business incubator in the external business environment. The business incubator thus attempts to overcome the 'liability of newness and the liability of smallness' for incumbent ventures (Bollingtoft 2012:304). Ideally, the business incubator should only incubate 'weakbut-promising' ventures (Bergek \& Norrman 2008:11). 'Weakbut-promising' entails that the entrepreneur(s) have a resource, or experience, or skills, or personality deficit yet possess a compelling business case (Hackett \& Dilts 2004:52). Mrkajic (2017:44) thus defines incubators as organisations that possess resources that are complimentary to the resources that incubates possess, and can be shared with incubates without incurring substantial costs. 


\section{Incubator services}

In this section, the manner in which incubator services have evolved will be examined, so that the business incubators within the province can be benchmarked against these services.

The essential services mix offered by business incubators have evolved over the last five decades. During the 1960s-1980s, business incubators offered only subsidised office or factory space, often referred to as subsidised rent (Allahar \& Brathwaite 2016:6; Bruneel et al. 2012:110; Mrkajic 2017:45; Pauwels et al. 2016:13; Theodorakopolous, Kakabadse \& McGowan 2014:6). This first-generation business incubator provided the entrepreneur with access to lower cost infrastructure and facilities by sharing costs amongst a community of tenants, but it failed to empower entrepreneurs (Bruneel et al. 2012:110; Mrkajic 2017:46).

The second-generation business incubator existed from 1980s to 1990s, and provided access to business development services such as expert training, coaching and mentorship through business professionals with the aim of accelerating the learning curves of tenant-entrepreneurs and gaining knowledge resources for operating a business venture (Allahar \& Brathwaite 2016:6; McAdam \& McAdam 2008:50; Mrkajic 2017:46; Theodorakopolous et al. 2014:6).

The third-generation of business incubators came into existence in the early 2000s with the emphasis on networking capabilities, access to expert technological, financial and professional knowledge capabilities, as well as raising finances for the incubated venture or creating access to a direct finance pipeline, and finally expediting and accelerating the commercialisation of technological innovations (Bruneel et al. 2012:110; Grimaldi \& Grandi 2005:112; Mrkajic 2017:46). To a large degree, access to business development services and real-estate provision became less pronounced and virtual incubation became the new norm (Mrkajic 2017:46; Pauwels et al. 2016:14). The following figure visually depicts the various generations with associated service offerings through which business incubators have evolved.

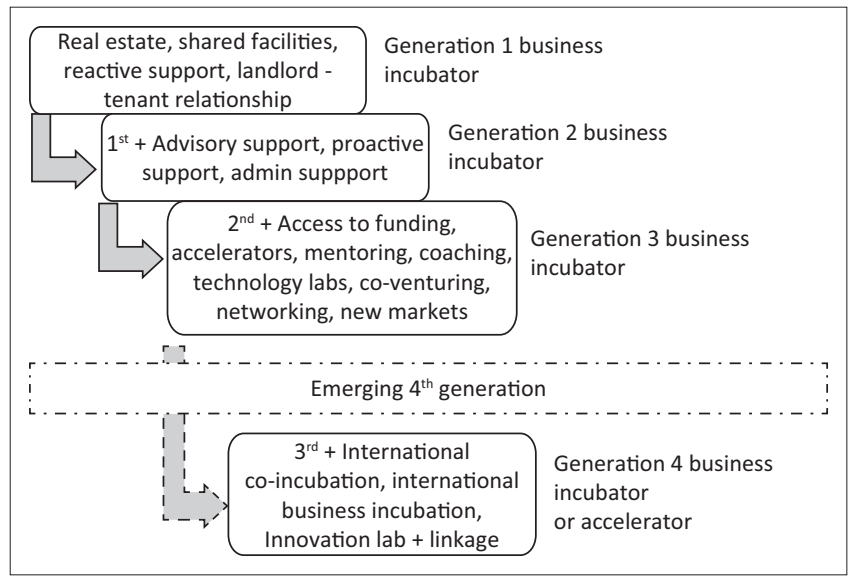

Source: Adapted from Allahar and Brathwaite (2016:6), Baraldi and Havenvid (2016:56), Theodorakopolous et al. (2014:6) and Mrkajic (2017:45)

FIGURE 2: Four generations of business incubation leading to accelerators.
In order to benchmark the service spectrum offered by incubators according to international standards, one must investigate the service spectrum offered by best practice business incubator models to date (Galiyeva \& Fuschi 2018:37; Olkiewicz et al. 2019:38; Torun et al. 2018:92). This is done in accordance with the generations of business incubation categorised by Allahar and Brathwaite (2016:6) and supported by the literature (Aerts, Matthyssens \& Vandenbempt 2007:258; Berendsen \& Beckett 2018:49; Bollingtoft 2012:306; Bruneel et al. 2012:113; Mrkajic 2017:45; Nair \& Blomquist 2018:5, 2019:271; Pauwels et al. 2016:13; Torun et al. 2018:92).

\section{Incubator generations with associated services}

These best practice models can be plotted historically from 1985 to 2017. The majority of academic best practice models offer access to physical premises (generation-one); admin support (generation two); and financial support, specialised (expert) skills and services, mentoring and networking (generation-three) concurrently and collectively. These best practice business incubator models include: Smilor (1987:148); Malecki and Nijkamp (1988:383); Wiggins and Gibson (2003:59); Soetanto (2004:5); Carayannis and Von Zedtwitz incubator model (2005:104); Deutschmann pre-incubator model (2007:11); Bergek and Norrman best practice business incubator model (2008:14); and Fominienè and Grigaitienè (2015:36). There are, however, best practice business incubator models that only offer generation-three services (as described above) without including generation-one and two services. These models include: Campbell, Kendrick and Samuelson (1985:46); Carter and Jones-Evans process incubator model (Aidin 2015:105; Moreira, Marta \& Carvalho 2012:45); Hackett and Dilts logic incubator and incubator process model (2004:44, 2008:441); O'Neal University incubator model (2005:4); Carayannis and Von Zedtwitz incubator model (2005:104); and Jones incubation value chain model (2010) as described by Fominienè and Grigaittiene (2017:35).

Models that include generation-two and three services but lack provision for generation-one services include the following models: Verman success factor incubator model (2004) as described by Gozali et al. (2015:6), Medibtikar business incubator model (Gadea 2016:329); Calza et al. incubator model (2014:606); and Gerlach and Brem generic business incubator model (2015:293). There are two best practice models that include generation-one services, as well as generation-three services. Firstly, Chandra and Chao's (2011:56) business incubation model which advocates external finance sources, network with university and physical facility provision. Secondly, Mrkajic conceptual framework for developing country business incubator model (2017:52) that advocates the development of new markets or expanding into new markets, business capability development and infrastructure development

Although the researcher argues that there are not yet a comprehensive fourth-generation best practice incubator model developed, there are a number of models that offer comprehensive generation-one, generation-two and generation-three services with incomplete elements of a 


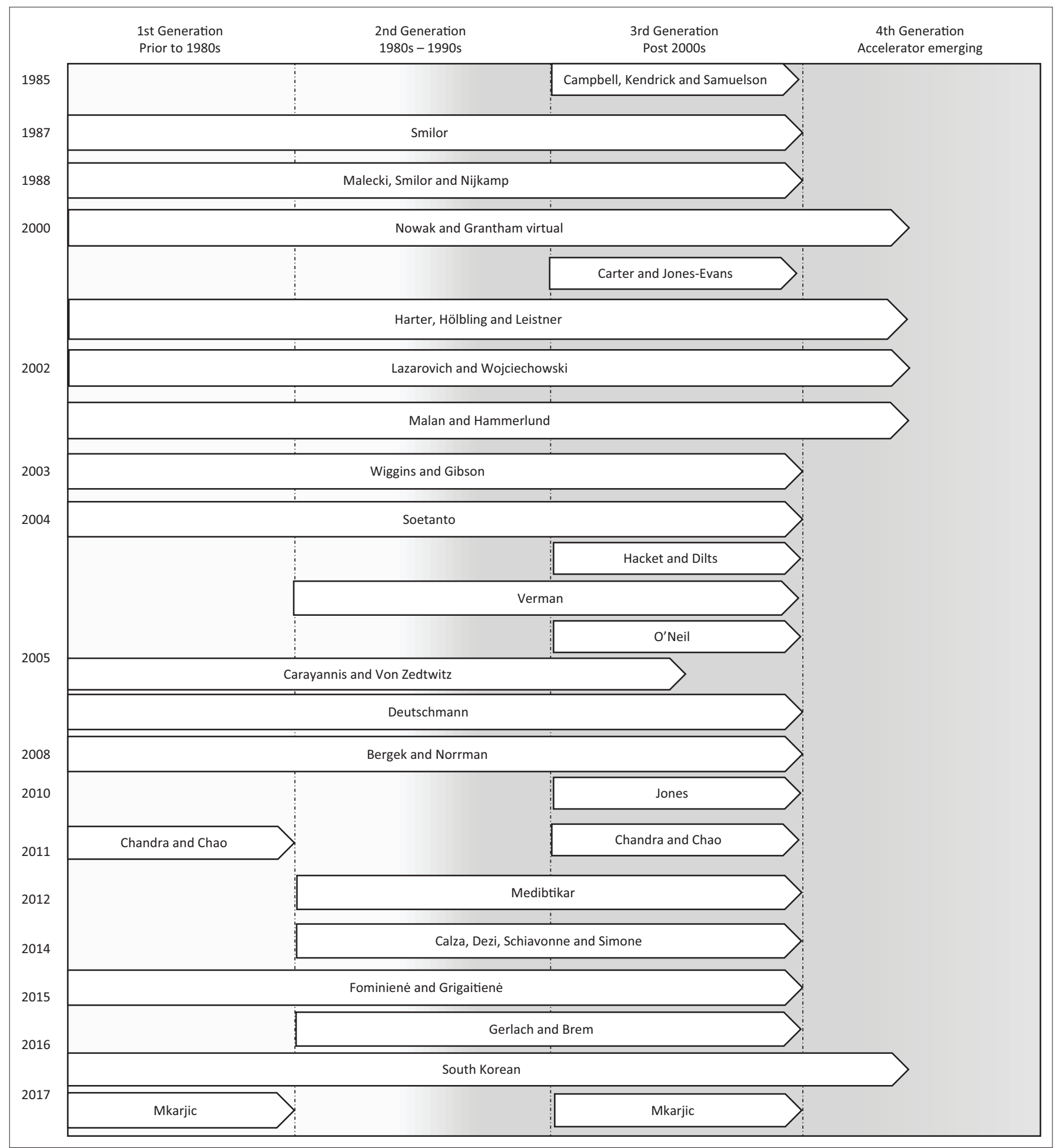

FIGURE 3: Service spectrum plotted over four generations of academic business incubator models

fourth-generation. These services include internationalisation of markets, co-incubation and international co-incubation. Models that offer these services are as follows: Harter, Hölbling and Leistner incubation model (2000:5); Nowak and Grantham virtual incubator model (2000:131); and Lazarowich and Wojciechowski new economy incubator model (2002:16). Other service elements of a fourthgeneration incubator are research and development and innovation labs. Incubator models that include these services are as follows: Malan and Hammerlund benchmark incubator model (2002:25); South-Korean business incubator model (Park \& Kim 2016:6); and Lazarowich and Wojciechowski new economy incubator model (2002:16).

\section{Research methodology Research design}

This study was executed according to a descriptive qualitative design. Such a design has the purpose of exploring a phenomenon by investigating different perspectives on a 
specific topic through identifying underlying themes that emerge through in-depth discussions with participants (Plano Clark \& Creswell 2015:289). As was discovered during the research fieldwork, business incubators in the Northern Cape Province visually advertise a wide array of services for incubator tenants. However, it was important to scrutinise this claim by interrogating participants on the actual services that they receive, not in theory, but in reality. This type of research design proved to be excellent in proving disparities between claimed service provision and actual service provision. A descriptive qualitative research design was thus very useful, as it unmasked all the themes associated with effective incubator service delivery, or the lack thereof, in the context of this study.

\section{Sampling}

The unit of analysis was business incubator tenants, staff and managers within the Northern Cape Province of the RSA. The sample consisted of 52 business incubator tenants and 11 incubator managers or incubator staff members. These participants were distributed amongst seven incubators in the province. According to the existing literature, there are fewer business incubators in existence within the province than were actually traced during this study. In a study by Lose et al. (2016:133), it was claimed that there are fewer than three public incubators and no private incubators within the province.

Another study by Masutha and Rogerson (2014:52) claimed that there was only one incubator in existence within the province and that this incubator was public.

A total of 63 semi-structured interviews were conducted. Data saturation is the point after which no new themes or patterns are identified within the data when analysing (Francis et al. 2010:2). Data saturation was achieved at interview 12; 63 participants were maintained eligible for this study in order to maintain site triangulation. Also, to access the most expletive quotations, the whole sample was kept into consideration. Keeping further interviews did thus provide some insights into the state of business incubation in the province and were considered. The distribution of participants can be found in Table 1 .

It was found that the incubators within the province typically only boast a single manager per incubator.

Thus, the manager at each of these locations within the sample was interviewed. Where incubator staff was on hand, they were also interviewed. This was done in order to avoid a bias towards the incubates. Both incubates and managers were thus able to state the services that were present or absent at each incubator.

In contrast to the other provinces of the RSA, the Northern Cape Province boasts only a handful of incubators. These entities were discovered to be hard to locate and to find. Most of them do not boast an online presence nor do some provide
TABLE 1: Sample size and particulars.

\begin{tabular}{lcccc}
\hline Incubator & $\begin{array}{c}\text { Number of } \\
\text { participants }\end{array}$ & $\begin{array}{c}\text { Managers } \\
\text { and staff }\end{array}$ & $\begin{array}{c}\text { Tenant- } \\
\text { entrepreneurs }\end{array}$ & $\begin{array}{c}\text { Average interview } \\
\text { length (min) }\end{array}$ \\
\hline Incubator 1 & 19 & 3 & 16 & 25 \\
Incubator 2 & 6 & 1 & 5 & 21 \\
Incubator 3 & 8 & 3 & 5 & 14 \\
Incubator 4 & 7 & 1 & 6 & 15 \\
Incubator 5 & 10 & 1 & 9 & 11 \\
Incubator 6 & 9 & 1 & 8 & 20 \\
Incubator 7 & 4 & 1 & 3 & 11 \\
\hline Total & $\mathbf{6 3}$ & $\mathbf{1 1}$ & $\mathbf{5 2}$ & $\mathbf{1 7}$ \\
\hline
\end{tabular}

contact details. Some of those whom are advertised have resulted in nothing and are no longer in existence or are completely dormant. In order to bridge this problem, purposive sampling was employed. This allowed the researcher to select all the incubators in the province that was relatively easy to find, and to get referrals to the less known and less traceable incubators within the province from role players within the province. Participants within the sample ranged from a very wide span of industries including stationary and office supplies, personnel and staffing solutions, catering and cooking, manufacturing, construction, transport, security, information and communications technology, automotive, jewellery and precious and semiprecious stones, and lastly, clothing and textiles. Thus, two purposive sampling strategies were used to sample participants: homogenous and snowballing.

Homogenous purposive sampling allows for the selection of participants based on certain predetermined characteristics in order to reduce variations and spearhead a more focussed investigation (Plano Clark \& Creswell 2015:334). The specific characteristics to comply with required an incubate, a service provider or a manager within a business incubator operation within the borders of the Northern Cape Province of the Republic of South Africa. The snowballing purposive sampling strategy required referrals from the initial participants targeted through the homogenous strategy (Plano Clark \& Creswell 2015:334; Polit \& Beck 2012:517).

\section{Data collection}

Data were collected from a semi-structured interview protocol utilised during interviews. All data collection was done in a personal face-to-face manner during a formal meeting that was pre-arranged with participants. The interviews lasted an average of $17 \mathrm{~min}$ per interview. Semistructured interviews enhanced the study notably by allowing for the researcher conducting the interviews to rephrase questions, or translate questions into alternative languages for participants with low levels of literacy. Afrikaans is a wider spoken language than English within the province and some participants were not able to understand or speak English at all. As the researcher is Afrikaans by mother tongue and thus fluent in this language, this proved to be an advantage for the research. The researcher could thus switch between English and Afrikaans as needed and translate where required. The semi-structured research protocol was overviewed and critiqued by a senior academic 
in the field of entrepreneurship prior to the pretest. The questionnaire was then pretested amongst 17 participants in a national South African context across provinces prior to implementation for this particular research. The pilot test allowed for amendments to the questions in the semistructured discussion guide as required. The pretest was done in a semi-structured face-to-face setting, with a single participant at a time.

\section{Data analysis}

Thematic analysis was applied to the analysis of data. Themes were analysed deductively and inductively.

Deductive analysis was done by performing a very comprehensive review of the existing themes on incubator services according to the literature. Inductive analysis was done by identifying patterns within the data collected and then connecting it to existing themes within the literature. According to Braun and Clarke (2012:60-69), there is a systematic process of extracting and analysing themes from the data. This systemised process was employed. Firstly, all interviews were recorded on a portable digital audio device and transferred to an external hard drive. Secondly, using improved audio playback, the researcher transcribed these recordings. Thirdly, the transcripts were loaded into Atlas.ti data analysis software whereby sub-themes were identified and then grouped into main themes. Reconciliation between patterns identified in the literature review, as well as in the data, assisted this activity. Fourthly, all notes were reviewed and revisited for a second round in order to reduce the possibility of erroneous and misallocated sub-themes and main themes. Fifthly, all themes were allocated a clear definition according to the reviewed literature. Lastly, the reporting of data and subsequent write-up was done according to the main themes which were directly linked to the research questions. Substantiating quotes were employed into the reporting to provide impetus to the findings.

\section{Trustworthiness}

In order for qualitative research to be trustworthy, it has to be credible, transferable, dependable and confirmable (Mostert, Niemann \& Kotze 2017:7). Site triangulation was employed in order to enhance credibility (Mostert et al. 2017:8; Niemann, Kotze \& Mannya 2018:7). This entailed including participants from multiple geographic areas and multiple independent incubators so that themes identified are not unique to only one incubator or a single geographic area. In order to achieve this, non-related participants from various geographic locations varying across the province were interviewed.

Transferability and authenticity was achieved by providing a detailed description of the participants, the data analysis technique, as well as a basic literature analysis of the research topic (Creswell 2007:209; Mostert et al. 2017:8; Niemann et al. 2018:7; Polit \& Beck 2012:585). Dual sources of data enhanced confirmability by strongly linking themes from the empirical findings to themes derived from the basic literature review; thus, two different sources of data were employed (Mostert et al. 2017:7; Vermeulen, Niemann \& Kotze 2016:8). Lastly, a peer debriefing of transcripts and data analysis were employed to enhance the dependability of the themes presented (Polit \& Beck 2012:594).

\section{Ethical considerations}

The study steered clear of psychologically and socially sensitive issues to avoid emotional harm to participants in the research. All participants for the research and data gathering offered consent to partake in the research. All participants in the research were briefed accordingly. Where required and applicable, consent was obtained from incubator management to interview incubate participants. All names have been withheld on the basis of anonymity and pseudonyms which are untraceable were used where needed. Also, prominent landmarks or features that would compromise anonymity were altered with neutral descriptions.

\section{Findings}

The data were analysed into themes which were listed categorically according to the frequency of occurrence, as well as known themes that were derived from the literature review.

\section{Incubator service spectrum}

This section will provide the findings to address research question one on the presence or absence of critical services within the business incubators of the province. The findings are listed below:

\section{Access to physical premises}

The most basic service that incubators are expected to provide is that of access to subsidised physical premises on which to conduct their business activities (Stefko \& Steffek 2017:251). Incubators one, two and three offered access to physical premises according to a reduced or subsidised rental agreement:

\footnotetext{
'You see, I'll be here as long as I can, because they're providing office space. If they provide business incubation, I should be here for a specific time. Most of the guys here, they are getting cheap space. They come here with the hope of business incubation, they're not getting. So they use it for space, office space.' (Incubator 1, transcript 6, participant 6, incubate, male)

'Yes, the rent is cheaper. The rent is cheaper. If I had to move out into town, I would pay three times the amount. Three times the amount. That's excluding water and lights. Here it's water and lights included, that's the plus.' (Incubator 1, transcript 12, participant 12 , incubate, female)
}

This type of service is typically associated with a firstgeneration incubator. The purpose of this service is to offer new start-ups, an enhanced chance of survival and increased competitiveness by lowering overhead expense, most notorious being rental expenses (Allahar \& Brathwaite 
2016:6; Bakkali et al. 2014:1; Lose \& Tengeh 2015:14346; Torun 2016:5). Incubators four, five, six and seven did not provide incubates with access to physical premises:

'The thing is, if I could get some storage, because I want to develop in such a way that I can supply other suppliers.' (Incubator 4, participant 36, transcript 36, male, incubate)

'For now, we are quite struggling of an office that we can work in. So we are actually looking for an office that we can work in, for clients to access us easily.' (Incubator 4, Participant 37, transcript 37 , male, incubate)

\section{Access to equipment}

A further basic service offering associated with generationone incubators is access to communal or specifically procured equipment such as machines and tools with which to produce outputs (Baraldi \& Havenvid 2016:56; Bollingtoft 2012:304; Indiran, Khalifah \& Ismail 2015:744). Incubator two and incubator three offered incubates access to equipment and machinery. Incubator two offered incubates generic equipment that was procured prior to incubates entering the facility, whilst incubator three procured specific equipment for every incubate according to unique needs after they have entered the facility:

'The incubator helped a lot, especially in the sense of starting up a factory. Before joining the incubator, we tried doing it on our own. We looked for funding, we looked for office space. Starting up a factory was going to cost us like about five million which we did not have. We're talking about almost the latest equipment to compete on the global market. So the incubator helped us a lot in the sense that we didn't have to worry about equipment, space, security and licensing etcetera. Basically everything was set up nicely. So it helped us, cause now if we look for funding, it was just for capital in terms of stock, the rest was already procured.' (Incubator 2, transcript 22, participant 22, incubate, male)

'Also with my assets, if I need something for my business urgently, they will then pay for me and I will have to pay them back within a certain period of time.' (Incubator 3, transcript 23, participant 23 , incubate, male)

\section{Administrative support}

Administrative support constitutes reception, secretarial support, access to internet or $\mathrm{Wi}-\mathrm{Fi}$, telephones, printing, copying and faxing facilities (Godeiro et al. 2018:5; James \& Maria 2017:29; Muñoz \& Cohen 2018:131; Njau et al. 2019a:20; Pauwels et al. 2016:14; Stefko \& Steffek 2017:258; Tengeh, Robertson \& Choto 2015:159). Incubators three, four, five and six offered access to $\mathrm{Wi}-\mathrm{Fi}$, internet access, telephones, printing and copying, as well as faxing facilities:

'Well, free internet, I am a website junky. So I am very grateful for the emails and phone calls I can make. OK, there's a limit, but, I always make enough. So, that's about it. That's the one thing I

TABLE 2: Access to physical premises.

\begin{tabular}{llllllll}
\hline Incubator & $\mathbf{1}$ & $\mathbf{2}$ & $\mathbf{3}$ & $\mathbf{4}$ & $\mathbf{5}$ & $\mathbf{6}$ & $\mathbf{7}$ \\
\hline Physical premises & $\checkmark$ & $\checkmark$ & $\checkmark$ & $\mathrm{X}$ & $\mathrm{X}$ & $\mathrm{X}$ & $\mathrm{X}$ \\
\hline
\end{tabular}

TABLE 3: Access to equipment.

\begin{tabular}{llllllll}
\hline Incubator & $\mathbf{1}$ & $\mathbf{2}$ & $\mathbf{3}$ & $\mathbf{4}$ & $\mathbf{5}$ & $\mathbf{6}$ & $\mathbf{7}$ \\
\hline Equipment & $\mathrm{X}$ & $\checkmark$ & $\checkmark$ & $\mathrm{X}$ & $\mathrm{X}$ & $\mathrm{X}$ & $\mathrm{X}$ \\
\hline
\end{tabular}

am grateful for, because we don't have it back home. (Incubator 6 , transcript 52, participant 52, incubate, male)

In addition, incubator three offered secretarial support as well as reception services to incubators:

'My strategic planning, my time management. If I'm having a difficulty, the admin manager will intervene and tell the other people that I have a deadline and no one should disturb me. Then tells the receptionist to cancel all my appointments. Even going the extra mile, calling the client and explaining why the order might be delayed or something like that. Just manages that time.' (Incubator 3, transcript 23, participant 23, incubate, male)

'We have an administrative officer allocated to us to work through our documentation, filing and stuff like that.' (Incubator 3 , transcript 23, participant 23 , incubate, male)

'From my side, which is admin, I help them a lot. With paperwork and so on. Not one of them has a laptop. We still have a problem with internet though as it has not been connected yet. So they come to me and I'll take their stuff further. If stuff needs to be emailed, I'll email it. If things need to be typed. I'll phone the incubates, WhatsApp them and phone. I don't even get a cell phone allowance.' (Incubator 5, transcript 50, participant 50, incubator employee, female)

Incubators one, two and seven offered no administrative support to the incubates whatsoever:

'They were supposed to help us with certain documents and, to my understanding, when they brought us in here, they were supposed to help us build the business. Not in terms of them going out to look for us, but how to approach certain places or the filling out of documents, or things like that, which they never did in the past.' (Incubator 1, transcript 1, participant 1, incubate, female)

\section{Access to finance}

Financial services provided to incubates should include access to seed capital, as well as bridging capital which can be sourced internally or externally (Herber et al. 2017:3070; Liu, Jang \& Hu 2018:974; Mansur \& Abuga 2017:157; Navarro 2018:305; Stefko \& Steffek 2017:252). Incubators one, four, five and six did not provide any form of internal capital investment:

'I'm struggling now, because I got a job from the government and I have to borrow money from this informal people that can borrow us money and then we must pay them $50 \%$ interest ... mashonisa. That is my challenge for now. It is dangerous. But then, we don't have a choice. You have not had business for the last 6 months, or three months. How is the bank going to give you money? You get my point? Even now, there's a contract of mine that is running in two towns at the same time. I have many clients. I have to buy them supplies. So if there was something in the incubator, maybe financial support. Even though it's not much. Maybe they can give us only when you've got your contract. I have this contract, please fund this contract for me. I have another project I implemented with many clients. I had to recruit them out of nothing. I had to implement the project out of nothing.'(Incubator 1, transcript 3, participant 3 , incubate, female)

TABLE 4: Access to administrative support

\begin{tabular}{llllllll}
\hline Incubator & $\mathbf{1}$ & $\mathbf{2}$ & $\mathbf{3}$ & $\mathbf{4}$ & $\mathbf{5}$ & 6 & 7 \\
\hline Administrative & $\mathrm{X}$ & $\mathrm{X}$ & $\checkmark$ & $\checkmark$ & $\checkmark$ & $\checkmark$ & $\mathrm{X}$ \\
\hline
\end{tabular}


'I went to them, I got work from a client to go somewhere and to provide a service but I didn't have the finance to do that, but was just looking for the money to just do the project, come back, put the invoice in and I'll pay. But they couldn't even assist with that. They let me do a whole finance report, I had to do a submission, through that whole process just to come back again and say, no, we can't assist.' (Incubator 1, transcript 7, participant 7, incubate, male)

Incubators two and three offered bridging capital investment to incubates. In both cases, this was done as a short-term loan whereby the incubate could use the funds to purchase equipment and stock needed to proceed with a commercial transaction. The source of capital for incubator two was external, whilst the source for incubator three was internal. Upon the completion of the transaction and receiving payment, the loan could be either serviced in payments or a single debt settlement payment. In addition, incubators three and seven could also provide seed capital to incubates where needed:

'So it was a loan. We basically got the raw materials. There wasn't much profitability but we managed to sell. Uh, so we paid half the loan back so that they can refinance.' (Incubator 2, transcript 22, participant 22, incubate, male)

'Incubates get an open loan account. For a recent contract I needed a big sum that I didn't have. So what the incubator did was they paid upfront for all of that, and when the client pays me the money, I pay them back. That's how my funding goes. For some entrepreneurs there are also seed-funding. This funding arrangement works perfectly.' (Incubator 3, transcript 23, participant 23, incubate, male)

Incubators two and six indicated that they assist incubates with applications to external financiers. These financiers were exclusively indicated to be the National Youth Development Agency (NYDA) and the Small Enterprise Finance Agency (SEFA). It was stated that none of these applications have been historically successful:

'I've applied for funding from government. They are partners to that. And, we've submitted our business plans to them. It was advertised more than 2 years ago. I've applied. Not one of us received funding. There were lots of guys applying. Um, not one of us received.' (Incubator 1, transcript 7, participant 7, incubate, female)

\section{Access to specialised skills and specialised services}

Specialised skills may be an internal capability or externally sourced capability and constitute technical support, marketing support, accounting and bookkeeping, legal support, business planning, business development support, general management expertise or any other professional skill required by the incubate (Baraldi \& Havenvid 2016:56; Calza et al. 2014:604; Deutschmann 2007:8; Gozali et al. 2015:121; Indiran et al. 2015:734; James \& Maria 2017:29; Stefko \& Steffek 2017:252). Incubators one, four, five and six did not offer any access to specialised skills:

TABLE 5: Access to finance.

\begin{tabular}{llllllll}
\hline Incubator & $\mathbf{1}$ & $\mathbf{2}$ & $\mathbf{3}$ & $\mathbf{4}$ & $\mathbf{5}$ & $\mathbf{6}$ & $\mathbf{7}$ \\
\hline Finance & $\mathrm{X}$ & $\checkmark$ & $\checkmark$ & $\mathrm{X}$ & $\mathrm{X}$ & $\mathrm{X}$ & $\checkmark$ \\
\hline
\end{tabular}

'I'm creative. In most cases I'm not really business orientated or admin orientated. You know, all those basic things like your bookkeeping, your financials, your marketing, like those kind of things. In most cases, this is what I do: I come in, I design. There's no people that says how are your books? Are you managing them correctly?' (Incubator 1, transcript 4, participant 4 , incubate, male)

'Firstly, they must get skilled people. You cannot present a service which you are not au fait with. Firstly, their managers, or staff, or whoever, they don't have business development skills or qualifications. Secondly, they don't have the skills to convince me to use them. In order for you to provide a service, you must be skilled. You must be au fait the field. What I've picked up, or what I know is that most of them are not qualified. In order to provide a service, you must have qualifications in that field.' (Incubator 1, transcript 6, participant 6, incubate, male)

Incubators two did offer some aspects of professional skills, yet it was explained that some were of an acceptable standard and useful, whilst others were of a poor standard and largely without use:

'There are people put in place to push you. You get a business developer, a technical advisor. If you need to know anything, if you need to learn anything, if you get stuck making something, that person is supposed to be there to help you, show you where you've gone wrong and help you make it better. That kind of thing. We're supposed to have an accountant. Um, there's a marketing person. All these people, did I mention the business developer? Um, there's like five entities, are there to push your business. You'll find within those five people, one or two will do their work, and the others like slack. For instance, the accountant does not do accounting. The accountant doesn't understand how to do accounting. I've gone to that person with accounting problems and I've asked that person to balance something for me, and that person told me about a textbook that she doesn't have. It's like going to a town planner and asking, 'oh, can you fill out his plan for me?', and he's like, oh I don't have my textbook. I don't work like that, but that's what they do. Um, the technician doesn't know most of the stuff. We keep showing the technician things to learn, but it's things like that that hold people back. They are trying to help me with marketing, but they can do better. For instance, I asked for one thing and they're not doing it. When I went overseas, I'm not really big on Facebook, which is like weird for me to say as a person in business because it should be one of my platforms. But, um, socially I think it's a lot of pretentious nonsense. But, um, my business page was linked to my personal page. When I left, I asked the marketing person, 'can I assign you to take care of that page?' The marketing person said 'sure' and we exchanged email addresses. The marketing person hasn't done a single thing; it's been four months now. So, other than that, this person does try and help, in the sense that if there's markets, that person will try and get us there. That person tries, but doesn't get everything.' (Incubator 2, transcript 24, participant 24, incubate, female)

Smaller and private micro-incubators presented a more successful approach with regard to providing specialised services. They would select only a handful of incubates carefully and ensure that enough internal expertise can be hired or procured, in order to accelerate the development of the incubates. This was the case with incubators three and seven: 
TABLE 6: Access to specialised skills and specialised services.

\begin{tabular}{llllllll}
\hline Incubator & $\mathbf{1}$ & $\mathbf{2}$ & $\mathbf{3}$ & $\mathbf{4}$ & $\mathbf{5}$ & $\mathbf{6}$ & $\mathbf{7}$ \\
\hline Skills and services & $\mathrm{X}$ & $\checkmark$ & $\checkmark$ & $\mathrm{X}$ & $\mathrm{X}$ & $\mathrm{X}$ & $\checkmark$ \\
\hline
\end{tabular}

TABLE 7: Access to mentorship.

\begin{tabular}{llllllll}
\hline Incubator & $\mathbf{1}$ & $\mathbf{2}$ & $\mathbf{3}$ & $\mathbf{4}$ & $\mathbf{5}$ & $\mathbf{6}$ & $\mathbf{7}$ \\
\hline Mentorship & $\mathrm{X}$ & $\mathrm{X}$ & $\checkmark$ & $\mathrm{X}$ & $\mathrm{X}$ & $\mathrm{X}$ & $\mathrm{X}$ \\
\hline
\end{tabular}

'So like I said, our professional services. If somebody needs help getting their intellectual property registered or getting help with bookkeeping services, they'll file an application and those people will come and assist them. Some of them are external, some of them are internal. We have different people that do different things. If we have to hire somebody to do something, we would, based on the value and the return on investment, depending on how this will change the start-up and how this will help the start-up to grow.' (Incubator 7, transcript 60, participant 60, incubator manager, female)

\section{Access to mentorship}

Mentorship in an incubation perspective encompasses a process of guiding incubates through various business activities such as business ideas, product development, sourcing resources, forming distribution and sales networks, as well as decision-making by experienced business practitioners (Ahsan et al. 2018:1; Dellermann et al. 2018:3; Sagath et al. 2019:6; Yusubova \& Clarysse 2016:8). In this study, incubator three was the only incubator found to offer mentorship services to tenant-entrepreneurs:

'They get funding. They get between R100 000.00 to R200 000.00 each. But they can't get the money. I manage the funds. I work for 12 months with about nine entrepreneurs a shot, and I have 12 months to work with them. We sit together with the funding, and they say "I want to buy this or I want to buy that", then I say, "No, you don't really want to buy that, it's not going to work. You have to do a little bit of this first". So, I coach them and I'm their business mentor for 12 months and help them.' (Incubator 3, transcript 33, participant 33, incubator manager, female)

'We have a one-on-one, where you can talk your heart out with us. If we see you really need help, then we go further to see if there's funding for your business.' (Incubator 3, transcript 23, participant 23, incubate, male)

\section{Access to training for skills development}

The most commonly encountered types of training are entrepreneurial, managerial (financial management, marketing management and growth management), legal and intellectual property as well as technical (Bagchi \& Chatterjee 2017:44; Dutt et al. 2016:821; Maraqa \& Darmawan 2016:31; Meru \& Struwig 2015:10; Sari 2018:39; Tselepis 2018:299). Incubators one, two and four offered no training for skills development:

'In terms of developing an SMME, obviously the cheap space helps, because it makes your business operational expenses much less, in terms of your rental. So it helps from a finance perspective. But in terms of what I know an SMME would need in terms of development, ah, there's nothing. So they got a nice board there, when you come in that's says we offer all these nice things here. But I haven't received not one of them... Whether
TABLE 8: Access to training for skills development.

\begin{tabular}{llllllll}
\hline Incubator & $\mathbf{1}$ & $\mathbf{2}$ & $\mathbf{3}$ & $\mathbf{4}$ & $\mathbf{5}$ & $\mathbf{6}$ & $\mathbf{7}$ \\
\hline Training & $\mathrm{X}$ & $\mathrm{X}$ & $\checkmark$ & $\mathrm{X}$ & $\checkmark$ & $\checkmark$ & $\checkmark$ \\
\hline
\end{tabular}

you'll be helping me with training, whether you'll be helping me with advisory services, whether you'll be helping me with specialised services that might benefit my particular need that I need in my business. Whether it's perhaps assisting me with access to market, or access to finance, nothing! Only thing that I receive here is the benefit of cheap office space that you won't find anywhere else.' (Incubator 1, transcript 11, participant 11, incubate, male)

Incubators three, five, six and seven did offer training to tenant-entrepreneurs for skills development. Incubator three offered technical and financial training. Incubator five provided tenant-entrepreneurs with practical technical training supplemented with classroom training on the government tender process. Incubator six provided classroom-based training on computer literacy, basic financial skills, basic marketing, business strategy, business planning and human resources management. Lastly, incubator seven offered computer-based business training:

'I attended a four-day training which was conducted by the incubator. My skills set. Remember, if you are a technical person, if you don't do anything about your skills, it sorts of diminishes in a sense. They help me a lot.' (Incubator 3, transcript 23, participant 23, incubate, male)

\section{Access to networks}

Types of networks include social networks, intra-entrepreneur networks (co-venturing), incubator-to-incubator networks (co-incubation), supplier networks, customer networks and finance networks (Alpenidze, Pauceanu \& Arab 2019:1; Baraldi \& Havenvid 2016:56; Bruneel et al. 2012:111; Gerlach \& Brem 2015:295; Indiran et al. 2015:737; Laino 2019:164; Lukeš, Longo \& Zouhar 2019:30; Miranda \& Borges 2019:36; Mohamad \& Chin 2019:596; Theodorakopolous et al. 2014:6; Torun 2016:5). Incubators one, five and six did not provide or facilitate any networking for the tenant-entrepreneurs:

'Never! Nothing! I was once in a meeting. Let them call the government, let us a have a roadshow. Let us be there and present our businesses to government, to people, you know. Nothing! Nothing! Nothing!' (Incubator 1, transcript 3, participant 3 , incubate, female)

Incubators two, three, four and seven did provide or facilitate networking opportunities for their tenant-entrepreneurs. Incubator two did provide both local and international networking opportunities to some of their tenantentrepreneurs by sponsoring a business exposition to national and international markets in order for the tenant-entrepreneurs to obtain clients and suppliers. Incubator four reported to assist tenant-entrepreneurs in finding suppliers and clients locally, whilst incubator seven linked its tenant-entrepreneurs with possible private funding partners and financiers:

'This year we went to national and international expos. And uh, right now our main clients came from that national expo. So it shows that we network locally and internationally and these 
events help us build clientele.' (Incubator 2, transcript 22, participant 22, incubate, male)

'OK, another advantage of being in the incubator, they approach stakeholders on our behalf. So that's another advantage of being part of the incubator, what can I say, it's a much stronger voice than if we, as an SMME, have to approach stakeholders on our own. So they approached them and linked us together.' (Incubator 3, transcript 23, participant 23, incubate, male)

Only incubator three provided evidence of co-venturing. There was no evidence of co-incubation within the sample population:

'Some of the other entrepreneurs have seed funding. So with that, my services are encapsulated within their seed funding. So they have to get a website, I do it for them. So there's certain amount of money I receive on the completion of their websites.' (Incubator 3, transcript 23, participant 23, incubate, male)

\section{Fourth-generation business incubator elements}

Elements of this type of incubator are international business incubation, international co-incubation and access to innovation labs (Allahar \& Brathwaite 2016:6; Baraldi \& Havenvid 2016:56; Mrkajic 2017:45; Theodorakopolous et al. 2014:6). Incubator two provided evidence of international incubation by exposing their tenant-entrepreneurs to international markets for both sales and procurement. No other business incubators within the sample population offered tenant-entrepreneurs access to international incubation:

TABLE 9: Access to networks.

\begin{tabular}{llllllll}
\hline Incubator & $\mathbf{1}$ & $\mathbf{2}$ & $\mathbf{3}$ & 4 & 5 & 6 & 7 \\
\hline Networks & $\mathrm{X}$ & $\checkmark$ & $\checkmark$ & $\checkmark$ & $\mathrm{X}$ & $\mathrm{X}$ & $\checkmark$ \\
\hline
\end{tabular}

TABLE 10: Fourth-generation business incubator elements.

\begin{tabular}{lccccccc}
\hline Incubator & $\mathbf{1}$ & $\mathbf{2}$ & $\mathbf{3}$ & $\mathbf{4}$ & $\mathbf{5}$ & $\mathbf{6}$ & $\mathbf{7}$ \\
\hline $\begin{array}{l}\text { International } \\
\text { incubation }\end{array}$ & $\mathrm{X}$ & $\checkmark$ & $\mathrm{X}$ & $\mathrm{X}$ & $\mathrm{X}$ & $\mathrm{X}$ & $\mathrm{X}$ \\
$\begin{array}{l}\text { International } \\
\text { co-incubation }\end{array}$ & $\mathrm{X}$ & $\mathrm{X}$ & $\mathrm{X}$ & $\mathrm{X}$ & $\mathrm{X}$ & $\mathrm{X}$ & $\mathrm{X}$ \\
Innovation lab & $\mathrm{X}$ & $\mathrm{X}$ & $\mathrm{X}$ & $\mathrm{X}$ & $\mathrm{X}$ & $\mathrm{x}$ & $\mathrm{X}$ \\
\hline
\end{tabular}

'Also, access to markets. The incubator liaising with Department of Economic Development liaising with Department of Trade and Industry. I went on an international trip through the incubator and the Department of Economic Development where it was basically for us to gain access to international markets. Being able to, from a government perspective, go seek access to markets.' (Incubator 2, transcript 22, participant 22, incubate, male)

There was no evidence of international co-incubation amongst any participants within the sample. Lastly, there was also no evidence of an innovation lab within the sample population. However, incubator six did have procured equipment such as $3 \mathrm{D}$ printers in their possession that are supposed to be utilised in an innovation lab, as well as dedicated space for an innovation lab. The equipment is still yet to be utilised and remains non-operational. This incubator has also attempted to stock the incubator with more necessary equipment to enable such a lab. However, the innovation lab is not yet established nor operational in this case and can thus not be considered:

'We've done a few small things, but nothing big, no. It's like clay, there's so many ideas, but sometimes we lack support. It's the second time I have applied for big machinery, to have a whole mechanical workshop layout here, laser cutter, 3D scanner, plasma cutter.' (Incubator 6, transcript 57, participant 57, incubator manager, male)

\section{International best practice model benchmarking}

This section attempts to address research question two by benchmarking the incubators of the province against international best practice models as listed in Figure 2.

When benchmarking the incubators within the Northern Cape Province of the RSA against the international best practice models, the following can be observed: incubator one offers only access to physical space, associated with a generation-one incubator. Thus, incubator one can be said to historically still be in the 1980s and compete only against generation-one incubators. Incubator two is arguably the most advanced of the incubators in the province benchmarking well with a

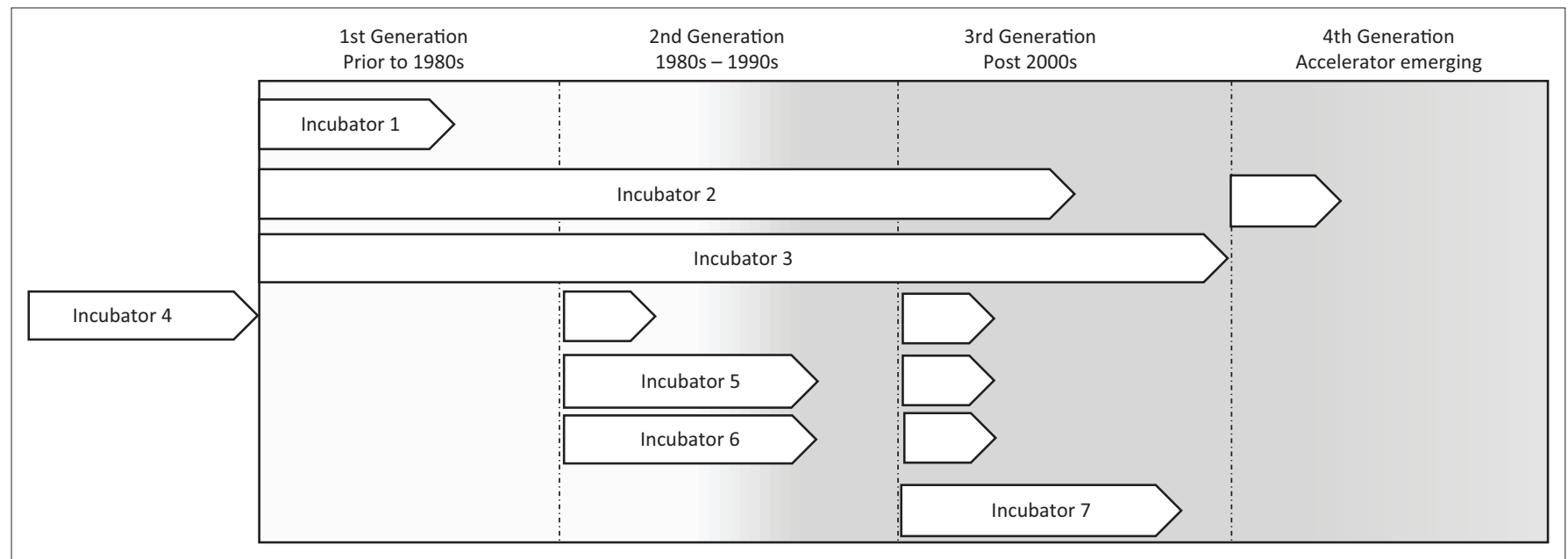

FIGURE 4: A benchmarking of Northern Cape incubators according to four generations of business incubator model service offerings. 
generation-three incubator, whilst offering a single element of a generation-four incubator. Incubator two compares the most favourable with international incubator models. However, the quality of each of these services is inconsequent, as can be seen when revisiting the previous section. Although most services are present, some are of good quality, some are of average quality and some are of poor quality. Incubator three benchmarks well against generation-three incubators and are definitely the most consistent incubator within the province. Participants within incubator three consistently and consecutively reported that all three generations of services present were of an acceptable quality. Thus, although it is not trail blazing in terms of generation-four services, it delivers stable and consistent performance in the third-generation bracket. Incubator four offers minute administrative support (generation two) and very limited networking (generation three) to tenant-entrepreneurs. It does not offer any generation-one services. Incubators five and six both offered incomplete service elements of generationtwo and generation-three incubators when benchmarked against best practice models. Some degree of administrative support and training were present in both. Over-reliance and dependence on relationships with state funding agencies were also present in both and reported a negligible success ratio. It is argued that both these incubators manifest service elements of a 1990s incubator and early 2000s incubator when benchmarked against best practice models. Incubator seven benchmarks well against a generation-three virtual incubator as it places a focus on training and skills development, access to specialised skills and services, networking with external financiers, as well as with external financiers as well as occasional internal funding. There is, however, a critical lack of business mentorship in this case that should be present in a generation-three virtual incubator. Incubator seven thus does not offer access to physical premises or communal equipment, hardware service elements of generation-one and generation-two business incubators.

\section{Conclusion}

\section{Summary of findings and theoretical implications}

The purpose of this study was to investigate the current spectrum of business incubation services that regional incubators in the Northern Cape offer to tenant-entrepreneurs or incubates and compare it with best practice incubator models. Research question one guided the study attempting to determine which spectrum of services regional incubators within the Northern Cape offer incubates. Incubator three offered the best service spectrum to tenant-entrepreneurs within the province by providing access to physical premises, communal and specific procured equipment, admin and secretarial support, training for skills development, access to specialised skills and services, networking, mentorship as well as financial support.

The delivery of these services was reported to be of good quality and consistent according to participants.

Incubates within incubator three reported that they were satisfied with this current service spectrum and did not need additional support. Incubator two is the only incubator that offered international incubation within the sample. In addition, incubator two also facilitated networking, access to specialised skills and services, access to finance along with access to physical premises and communal equipment. Incubator two had certain shortcomings in its offering, specifically mentorship, training for skills development and access to administrative support. However, incubator two reported varying levels of satisfaction amongst participants.

Some services rendered were of a good quality, whilst others were dormant or of a very poor quality.

Incubators one, four, five and six reported extremely low spectrums of services, and the researcher argues that they should not be classified as incubators, even though they are labelled as incubators in name. Incubator seven compares well with virtual incubators offering training for skills development, access to finance and networks. However, there is a critical shortage of mentorship. As a virtual incubator, they are not in the practice of providing office space or equipment.

Research question two further guided the study by attempting to determine how the spectrum of services of Northern Cape regional incubators benchmarks against business incubator best practice models. Incubator three was the only incubator in the sample that benchmarks competitively with best practice models.

Incubators two and seven are both fairly functional even though they have critical shortcomings in their offerings as discussed prior. Thus, they benchmark average against best practice models. With regard to the remainder of the sample, it paints a rather grim picture of dysfunctionality boasting major shortages in their service spectrum. Incubators one, four, five and six benchmark poorly against best practice models. On average thus, the majority of business incubators within the province are in a very poor state.

\section{Practical implications}

The findings of this study provide important insights into the state of business incubation within the Northern Cape Province from a service delivery perspective. In order to alleviate unemployment, create entrepreneurs and spark regional economic development, a standardised business incubator model is needed. Firstly, it is recommended that business incubators recruit service providers, consultants or incubator employees that are truly skilled and experienced in the field of SMME development. It is recommended that service providers, consultants or employees have in-depth knowledge, practical experience and creativity in frequently required disciplines such as marketing incubate businesses, business finances, bookkeeping, legal assistance, technical assistance and personal guidance of entrepreneurs. If these positions are not occupied by individuals that are truly experienced and skilled in their fields, one can expect poor results within the province. In addition, mentorship should 
be performed through real entrepreneurs that are experienced and versed in the challenges of being an entrepreneur. Secondly, mentorship should not be placed at the feet of civil servants that have no experience in business ownership nor understand the mind-set of an entrepreneur. Thirdly, it is recommended that incubators diminish their reliance on state funding agencies and focus on developing private funding pipelines or networks in addition to open multiple pipelines of financial assistance possibilities. Fourthly, training must be implemented to bring both incubates and the incubators up to date with the national and provincial landscapes and policies related to SMME development. A training curriculum developed by academia and experienced entrepreneurs that are standardised for public incubators is recommended. This will ensure that training programmes of acceptable and standardised quality are delivered all over the province. Fifthly, the physical spaces that are provided to entrepreneurs must possess basic amenities such as internet and Wi-Fi access, telephone and fax services and a courteous front desk officer whom can receive and direct interactions with environment outside the incubator. Sixthly, it is recommended that incubators plan and orchestrate focussed networking events between the consumers and suppliers of resources. Such events must facilitate the exploration of new markets, new sources of funding, critical skills and sources of materials. Lastly, it is tempting to recommend that incubators in the province attempt co-incubation amongst themselves. However, given the dysfunctionality of each at this point in time, it is advised that each incubator restructures and reorganises itself internally prior to attempting co-incubation. In addition, there may be merit in public incubators within the province sharing resources collectively. In such a manner, the already expensive resources needed will not be duplicated but rather shared. This should theoretically be possible as public incubators are not destined to be in opposition of one another but rather to promote the economic welfare of the province as a whole. From a private incubator perspective, this becomes improbable as the profit motive and private targets create competition amongst individual incubators.

\section{Research limitations and future research}

This study did not attempt to provide evidence of the effect that poor service provision had on tenant-entrepreneurs or incubates. This is a clear limitation of this research but also offers a research question for potential future research: Future research question one: what is the effect of poor service provision by Northern Cape business incubators on the tenant-entrepreneurs and ventures they attempt to incubate?

Furthermore, the study also did not investigate the obstacles to successful incubation within the province and therefore provides a second potential research question: Future research question two: what are the potential obstacles to successful business incubation within the Northern Cape Province from a tenant-entrepreneur or incubate perspective?

These two potential research questions will provide future research possibilities for researchers that can build on the trajectory of this initial research article.

\section{Acknowledgements Competing interests}

The author declares that he has no financial or personal relationships that may have inappropriately influenced him in writing this article.

\section{Author's contributions}

This is the original work of the author. The author conceptualised the article, performed the literature review, developed the research instrument and, lastly, wrote the article.

\section{Ethical consideration}

This article followed all ethical standards for carrying out research.

\section{Funding information}

This research received no specific grant from any funding agency in the public, commercial or not-for-profit sectors.

\section{Data availability statement}

Data sharing is not applicable to this article as no new data were created or analysed in this study.

\section{Disclaimer}

The views and opinions expressed in this article are those of the author and do not necessarily reflect the official policy or position of any affiliated agency of the author.

\section{References}

Aernoudt, R., 2004, 'Incubators: Tool for entrepreneurship?', Small Business Economics 23(2), 127-135. https://doi.org/10.1023/B:SBEJ.0000027665.54173.23

Aerts, K., Matthyssens, P. \& Vandenbempt, K., 2007, 'Critical role and screenin practices of European business incubators', Technovation 27(5), 254-267. https:// doi.org/10.1016/j.technovation.2006.12.002

Ahmad, A.J., 2014, 'A mechanisms-driven theory of business incubation', International Journal of Entrepreneurial Behaviour \& Research 20(4), 375-405. https://doi. org/10.1108/IJEBR-11-2012-0133

Ahmed, M., 2017, A province of vast opportunity, viewed 29 March 2018, from https://www.fin24.com/Economy/a-province-of-vast-opportunity-20170310.

Ahsan, M., Zheng, C., DeNoble, A. \& Musteen, M., 2018, 'From student to entrepreneur: How mentorships and affect influence student venture launch' Journal of Small Business Management 56(1), 76-102. https://doi.org/10.1111/ jsbm.12362

Aidin, S., 2015, 'New venture creation: Controversial perspectives and theories', Economic Analysis 48(3-4), 101-109.

Albort-Morant, G. \& Oghazi, P., 2016, 'How useful are incubators for new entrepreneurs?', Journal of Business Research 69(2016), 2125-2129. https://doi. org/10.1016/j.jbusres.2015.12.019

Allahar, H. \& Brathwaite, C., 2016, 'Business incubation as an instrument of innovation: The experience of South America and the Caribbean', International Journal of Innovation 4(2), 71-85. https://doi.org/10.5585/iji.v4i2.107

Alpenidze, O., Pauceanu, A.M. \& Arab, U., 2019, 'Key success factors for business incubators in Europe: An empirical study', Academy of Entrepreneurship Journal 25(1), 1-13.

Babalola, S.S. \& Agbenyegah, A.T., 2016, 'Rural entrepreneurship: An insight into impeding factors influencing micro-entrepreneurial growth', Journal of Applied Business Research 32(6), 1751-1760. https://doi.org/10.19030/jabr.v32i6.9821

Badenhorst, D.H.S., Van der Westhuizen, C.A., Britz, E., Burger, M.C. \& Ferreira, N., 2018, 'Lost to follow-up: Challenges to conducting orthopaedic research in South Africa', South African Medical Journal 108(11), 917-921. https://doi.org/10.7196/ SAMJ.2018.v108i11.13252 
Bagchi, N. \& Chatterjee, K., 2017, 'Identification of gaps in performance of services provided to start-ups in high technology, low technology and social \& agriprovided to start-ups in high technology, low technology and social \& agri-
business incubation centers in India: Constraints to growth', ASCI Journal of Management 45(1), 35-46.

Bailey, H.A., 2019, 'The challenge of late payment of SMMEs with a focus on South Africa', in F. Bode (ed.), Universities, Entrepreneurship and Enterprise Development in Africa - Conference Proceedings 2018, Sankt Augustin, Germany, September in Africa-Conference Proc

Bakkali, C., Messeghem, K. \& Sammut, S., 2014, 'Toward a typology of incubators based on HRM', Journal of Innovation and Entrepreneurship 3(3), 1-10. https:// doi.org/10.1186/2192-5372-3-3

Bank, N., Fichter, K. \& Klofsten, M., 2016, 'Sustainability-profiled incubators, regional factors and the recruiting of tenants', RENT-Conference, Antwerp University, Belgium, November 16-18, 2016, pp. 1-12.

Baraldi, E. \& Havenvid, M.I., 2016, 'Identifying new dimensions of business incubation: A multi-level analysis of Karolinska Institute's incubation system', Technovation 50(51), 53-68. https://doi.org/10.1016/j.technovation.2015.08.003

Battistella, C., De Toni, A. \& Pessot, E., 2018, 'Framing open innovation in start-ups' incubators: A complexity theory perspective', Journal of Open Innovation: Technology Market, and Complexity 4(3), 1-14. https://doi.org/10.3390/joitmc4030033

Beangstrom, P., 2017, Nearly 50\% of Northern Cape without jobs, viewed 29 March 2018, from https://www.iol.co.za/news/south-africa/northern-cape/nearly-50of-northern-cape-without-jobs-10737683.

Beangstrom, P., 2018, Northern Cape has biggest drop in unemployment rate, viewed 29 March 2018, from https://www.dfa.co.za/news/northern-cape-has-biggestdrop-in-unemployment-rate/.

Beer, A., Ayres, S., Clower, T., Faller, F., Sancino, A. \& Sotarauta, M., 2019, 'Place leadership and regional economic development: A framework for cross-regional analysis', Regional Studies 53(2), 171-182. https://doi.org/10.1080/00343404. analysis', Regional
2018.1447662

Berendsen, G. \& Beckett, R.C., 2018, Business models within business models: Two incubator case studies, pp 47-57, viewed 04 March 2019 from https://indietopia. org/wp-content/uploads/2018/10/berendsen-beckett-cinet2018-fp-1.pdf.

Bergek, A. \& Norrman, C., 2008, 'Incubator best practice: A framework', Technovation 28(2008), 20-28. https://doi.org/10.1016/j.technovation.2007.07.008

Beugelsdijk, S., Klasing, M.J. \& Milionis, P., 2019, 'Value diversity and regiona economic development', The Scandinavian Journal of Economics 121(1), 153-181. https://doi.org/10.1111/sjoe.12253

Biyase, M. \& Zwane, T., 2018, 'An empirical analysis of the determinants of poverty and household welfare in South Africa', The Journal of Developing Areas 52(1), 115-130. https://doi.org/10.1353/jda.2018.0008

Bollingtoft, A., 2012, 'The bottom-up business incubator: Leverage to networking and cooperation practices in a self-generated, entrepreneurial-enabled environment', Technovation 32(2012), 304-315. https://doi.org/10.1016/j.technovation.2011. 11.005

Bose, M.S. \& Goyal, D., 2018, 'Critical success factors of agri-business incubators and their impact on business performance', Custos e Agronegocio On Line 14(4), 350-376.

Braun, V. \& Clarke, V., 2012, 'Thematic analysis', in H. Cooper (ed.), APA handbook of research methods in psychology, vol. 2, pp. 57-71, American Psychological Association, Washington, DC.

Bruneel, J., Ratinho,T., Clarysse, B. \& Groen, A., 2012, 'The evolution of business incubators: Comparing demand and supply of business incubation services across different incubator generations', Technovation 32(2012), 110-121. https://doi. different incubator generations', Techno
org/10.1016/j.technovation.2011.11.003

Caetano, D., Preto, M.T. \& Amaral, M., 2019, 'University-industry linkage through business incubation: A case study of the IPN incubator in Portugal', in H. Almeida $\&$ B. Sequeira (eds.), The role of knowledge transfer in open innovation (pp. 223244), IGI Global, Hershey, PA.
B. Sequeira (eds.), The role

Calza, F., Dezi, L., Schiavone, F. \& Simone, M., 2014, 'The intellectual capital of busines incubators', Journal of Intellectual Capital 15(4), 597-610. https://doi. org/10.1108/JIC-07-2014-0086

Campbell, C., Kendrick, R.C. \& Samuelson, D.S., 1985, 'Stalking the latent entrepreneur: Business incubators and economic development', Economic Development Review $3(2), 43-49$.

Carayannis, E.G. \& Von Zedtwitz, M., 2005, 'Architecting gloCal (global-local), real-virtua incubator networks (G-RVINs) as catalysts and accelerators of entrepreneurship in transitioning and developing economies: Lessons learned and best practices from current development and business incubation practices', Technovation 25(2005) 95-110. https://doi.org/10.1016/S0166-4972(03)00072-5

Chandra, A. \& Chao, C.A., 2011, 'Growth and evolution of high-technology business incubation in China', Human Systems Management 30(2011), 55-69.

Creswell, J.W., 2007, Qualitative inquiry and research design: Choosing among five approaches, 2nd edn., Sage, Thousand Oaks, CA

Dellermann, D., Lipusch, N., Ebel, P. \& Leimeister, J.M., 2018, 'Design principles for a hybrid intelligence decision support system for business model validation', in Electronic markets 29(3), 423-441. https://doi.org/10.1007/s12525-018-0309-2

Deutschmann, M., 2007, What difference a'pre'makes: University business preincubators in Germany, pp. 1-10, A national survey (No. 5), Lüneburge Beiträge zur Gründungsforschung, Leuphana Universität Lüneburg, Lehrstuhl Gründungsmanagement, Lüneburg.

DeVaughn, M.L. \& Leary, M.M., 2018, 'Learn by doing or learn by failing? The paradoxical effect of public policy in averting the liability of newness', Group \& Organization Management 43(6), 871-905. https://doi.org/10.1177/1059601 116674826
Du Toit, M., De Witte, H., Rothmann, S. \& Van den Broeck, A., 2018, 'Unemployment experiences in context: A phenomenological study in two townships in South Africa', Journal of Psychology in Africa 28(2), 122-127. https://doi.org/10.1080/1 4330237.2018.1454575

Dutt, N., Hawn, O., Vidal, E., Chatterii, A., McGahan, A. \& Mitchell, W., 2016, 'How open system intermediaries address institutional failures: The case of business incubators in emerging-market countries', Academy of Management Journa 59(3), 818-840. https://doi.org/10.5465/amj.2012.0463

Dvouletý, O., Longo, M.C., Blažková, I., Lukeš, M. \& Andera, M., 2018, 'Are publicly funded Czech incubators effective? The comparison of performance of supported and non-supported firms', European Journal of Innovation Management 21(4), 543-563. https://doi.org/10.1108/EJIM-02-2018-0043

Faber, B. \& Gaubert, C., 2019, 'Tourism and economic development: Evidence from Mexico's coastline', American Economic Review 109(6), 2245-2293. https://doi. org/10.1257/aer.20161434

Famiola, M. \& Hartati, S., 2018, 'Entrepreneurship learning system in business incubators: A case study in Indonesia', International Journal of Engineering \& Technology 7(4.28), 57-62.

FindTripInfo.co.za, 2014, A travel guide to the countries of Africa compiled by local destination specialists, Map of the Northern Cape, viewed 25 August 2019, from http://www.findtripinfo.com/south-africa/northern-cape/diamond-fields.html.

Fominienè, A. \& Grigaitienè, V., 2017, 'Assessment of the feasibility to improve business incubation process', Regional Formation and Development Studies 21(1), 34-42. https://doi.org/10.15181/rfds.v21i1.1407

Francis, J.J., Johnston, M., Robertson, C., Glidewell, L., Entwistle, V., Eccles, M.P. et al., 2010, 'What is an adequate sample size? Operationalising data saturation for theory-based interview studies', Psychology and Health 25(10), 1229-1245. https://doi.org/10.1080/08870440903194015

Fransman, T. \& Yu, D., 2018, Multidimensional poverty in South Africa in 2001-2016, No. $07 / 2018$, pp. 1-41, Department of Economics, Stellenbosch University, Stellenbosch. https://doi.org/10.1080/0376835X.2018.1469971

Gadea, E.S., 2016, 'Economic and social profitability of the incubators of the Valencian community during the period 2004-2014', University of Alicante, Doctoral thesis.

Galiyeva, N. \& Fuschi, D.L., 2018, 'A research proposal for measuring the effectiveness of business incubators', Journal of Organisational Studies and Innovation 5(3), 32-46.

Gerlach, S. \& Brem, A., 2015, 'What determines a successful business incubator? Introduction to an incubator guide', International Journal of Entrepreneurial Venturing 7(3), 286-307. https://doi.org/10.1504/IJEV.2015.071486

Godeiro, D.P.D.O., Dantas, M.L.R., Silva, D.C.D. \& Celestino, M.D.S., 2018, 'Application of importance and performance matrix to assess the quality of services provided by business incubators', Iberoamerican Journal of Entrepreneurship and Small Business 7(2), 01-30. https://doi.org/10.14211/regepe.v7i3.704

Gozali, L., Maslin, M., Haron, H.N. \& Zagloel, T.Y.M., 2015, 'Critical success factors of successful e-business incubators framework in Indonesian public universities' The Asian Journal of Technology Management 8(2), 118-131. https://doi. org/10.14716/ijtech.v9i5.1363

Gozali, L., Masrom, M., Zagloel, T.Y.M., Haron, H.N., Dahlan, D., Daywin, F.J. et al., 2018 'Critical success and moderating factors effect in Indonesian public universities' business incubators', International Journal of Technology 9(5), 1049-1060.

Grimaldi, R. \& Grandi, A., 2005, 'Business incubators and new venture creation: An assessment of incubation models', Technovation 25(2005), 111-121. https://doi org/10.1016/S0166-4972(03)00076-2

Guerrero, M., Urbano, D., Cunningham, J.A. \& Gajon, E., 2018, 'Determinants of graduates' start-ups creation across a Multi-Campus Entrepreneurial University: The case of Monterrey Institute of Technology and Higher Education', Journal of Smal Business Management 56(1), 150-178. https://doi.org/10.1111/jsbm.12366

Hackett, S.M. \& Dilts, D.M., 2004, 'A real options-driven theory of business incubation', The Journal of Technology Transfer 29(1), 41-54. https://doi.org/10.1023/ B:JOTT.0000011180.19370.36

Hackett, S.M. \& Dilts, D.M., 2008, 'Inside the black box of business incubation: Study B - Scale assessment, model refinement, and incubation outcomes'. The Journal of Technology Transfer 33(5), 439-471. https://doi.org/10.1007/s10961-007-9056-9

Harter, G., Hölbling, K. \& Leistner, S., 2000, 'Corporate incubation - A new approach to innovation', Booz-Allen \& Hamilton 6(3), 1-6.

Hausberg, J.P. \& Korreck, S., 2018, 'Business incubators and accelerators: A co-citation analysis-based, systematic literature review', The Journal of Technology Transfer 2018(January), 1-26. https://doi.org/10.1007/s10961-018-9651-y

Herber, D.L., Mendez-Hinds, J., Miner, J., Sedam, M.C., Wozniak, K., McDevitt, V.L. et al., 2017, 'University seed capital programs: Benefits beyond the loan', Technology \& Innovation 18(4), 305-314. https://doi.org/10.21300/18.4.2017.305

Honig, B. \& Karlsson, T., 2010, 'Social capital and the modern incubator: A comparison of in-group and out-group social networks', Journal of Small Business and Entrepreneurship 23(2010), 719-731. https://doi.org/10.1080/08276331.2010. 10593512

Indiran, I., Khalifah, Z., \& Ismail, K., 2015, 'A historical review of business incubation models', Proceedings of the 4th International Seminar on Entrepreneurship and Business (ISEB2015), pp. 2-751, Universiti Malaysia Kelantan, Pentan.

Ikebuaku, K. \& Dinbabo, M., 2018, 'Beyond entrepreneurship education: Business incubation and entrepreneurial capabilities', Journal of Entrepreneurship in Emerging Economies 10(1), 154-174. https://doi.org/10.1108/JEEE-03-2017-0022

InfoDev, 2014, An evaluation and impact assessment of Business Incubation Models in Eastern Europe and Central Asia: An InfoDev study of nine business incubators in Armenia, Belarus, Kazakhstan, Poland, Romania, the Russian Federation, Serbia and Turkey, The World Bank, Washington, DC, pp. 1-134. 
Isabelle, D., 2013, 'Key factors affecting a technology entrepreneur's choice of incubator or accelerator', Technology Innovation Management Review 3(2), of incubator or accelerator', Technology Innov

Jacobs, L., Du Preez, E. \& Fairer-Wessels, F., 2019a, Rough road to the stars: A route development framework for Astro Tourism in the Karoo arid region, Travel and Tourism Research Association: Advancing Tourism Research Globally, pp. 88 viewed 04 March 2019, from https://scholarworks.umass.edu/ttra/2019/research_ papers $/ 88$.

Jacobs, L., Du Preez, E.A. \& Fairer-Wessels, F., 2019b, 'To wish upon a star: Exploring Astro tourism as vehicle for sustainable rural development', Development Southern Africa 2019, 1-18. https://doi.org/10.1080/0376835X.2019.1609908

James, D.W. \& Maria, P.A., 2017, 'Marketing challenges for South African public sector business incubators', Journal of Competitiveness 9(4), 19-39. https://doi. org/10.7441/joc.2017.04.02

Jones, M., 2010, 'How to create an award winning incubator?', 9th Annual Conference: Best Practices in Science Based Incubation, Liverpool, United Kingdom, 17-19th November, n.p.

Kapinga, A.F., Montero, C.S., Mwandosya, G.I. \& Mbise, E.R., 2018, 'Exploring the contribution of business and technology incubators to women entrepreneurs' business development in Dar es Salaam, Tanzani', Journal of Global Entrepreneurship Research 8(1), 1-14. https://doi.org/10.1186/s40497-018-0111-9

Kepenek, E.B. \& Eser, Z., 2018, 'Impact of pre-incubators on entrepreneurial activities in Turkey: Problems, successes, and policy recommendations', in D. Meissner, E. Erdil \& J. Chataway (eds.), Innovation and the Entrepreneurial University pp. 57-82, Springer, Cham.

Laino, A., 2019, 'Technological transfer in Italy: From University to the Industry: Brief analysis', International Journal of Academic Research in Business and Socia Sciences 9(3), 157-168. https://doi.org/10.6007/IJARBSS/v9-i3/5645

Lamine, W., Mian, S., Fayolle, A., Wright, M., Klofsten, M. \& Etzkowitz, H., 2018 'Technology business incubation mechanisms and sustainable regional development', The Journal of Technology Transfer 43(5), 1121-1141. https://doi. org/10.1007/s10961-016-9537-9

Lazarowich, M. \& Wojciechowski, M.J., 2002, Russian business incubator program, phase one: Prospect development and strategic plan, pp. 1-40, School of Planning, University of Waterloo, Waterloo, ON.

Li, C., Ur Rehman, H. \& Asim, S., 2019, 'Induction of business incubator centers in educational institutions: An effective approach to foster entrepreneurship', Journal of Entrepreneurship Education 22(1), 1-12.

Lilenstein, K., Woolard, I. \& Leibbrandt, M., 2018, '23 In-work poverty in South Africa: The impact of income sharing in the presence of high unemployment', in I. Marx \& H. Lohmann (eds.), Handbook on in-work poverty, Southern Africa Labour and H. Lohmann (eds.), Handbook on in-Work poverty, Southern Africa Labour and
Development Research Unit Working Papers 193, p. 416, SALDRU, University of Development Research
Cape Town, Cape Town.

Liu, J., Jiang, X. \& Hu, X., 2018, 'Research on the status quo and countermeasures of college students' entrepreneurship incubator platform construction of college students entrepreneurship incubator platform construction -
Take Yulin college as an example', In 8th International Conference on Social Network, Communication and Education (SNCE 2018), Shenyang, China, 2-4 Network, Com

Littlewood, D. \& Holt, D., 2018, 'Social entrepreneurship in South Africa: Exploring the influence of environment', Business \& Society 57(3), 525-561. https://doi. org/10.1177/0007650315613293

Lose, T., Nxopo, Z., Maziriri, E. \& Madinga, W., 2016, 'Navigating the role of business incubators: A review on the current literature on business incubation in South Africa', Acta Universitatis Danubius. Economica 12(5), 130-140. https://doi. Africa', Acta Universitatis
org/10.3390/su71014344

Lose, T. \& Tengeh, R.K., 2015, 'The sustainability and challenges of business incubators in the Western Cape Province, South Africa', Sustainability 7(2015), 14344-14357. https://doi.org/10.3390/su71014344

Lukeš, M., Longo, M.C. \& Zouhar, J., 2019, 'Do business incubators really enhance entrepreneurial growth? Evidence from a large sample of innovative Italian start-ups', Technovation 82, 25-34. https://doi.org/10.1016/j.technovation.2018.07.008

Mahadea, D. \& Kaseeram, I., 2018, 'Impact of unemployment and income on entrepreneurship in post-apartheid South Africa: 1994-2015', The Southern African Journal of Entrepreneurship and Small Business Management 10(1), 1-9. https://doi.org/10.4102/sajesbm.v10i1.115

Mahmood, N., Jianfeng, C., Munir, H., Yanran, M. \& Cai, Y., 2016, 'Incubators, SMEs, and economic development of China', International Journal of Multimedia and Ubiquitous Engineering 11(1), 311-318. https://doi.org/10.14257/ijmue.2016.11.1.29

Malan, J. \& Hammarlund, C., 2002, Benchmarking of business incubators, European Commission Enterprise Director-General, Centre for Strategy \& Evaluation Services, pp. 1-30, viewed 04 March 2019, from http://businessincubation.com. au/wp-content/uploads/benchmarking-incubators.pdf.

Malecki, E.J. \& Nijkamp, P., 1988, 'Technology and regional development: Some thoughts on policy', Environment and Planning: Government and Policy 6(1988), 383-399. https://doi.org/10.1068/c060383

Mansoori, Y., Karlsson, T. \& Lundqvist, M., 2019, 'The influence of the lean startup methodology on entrepreneur-coach relationships in the context of a startup accelerator', Technovation 84-85(June-July), 37-47. https://doi.org/10.1016/j. technovation.2019.03.001

Mansur, M.S. \& Abuga, I., 2017, 'Incubator based activities and technology entrepreneurship growth in North Western Nigeria', KIU Journal of Humanities 2(1), 157-168.

Maraqa, A. \& Darmawan, A., 2016, 'Enhancing the role of networked business incubators as a catalyst of promoting trading business among OIC', International Journal of Islamic Business 1(1), 29-49.
Masutha, M. \& Rogerson, C.M., 2014, 'Small business incubators: An emerging phenomenon in South Africa's SMME economy', Urbani Izziv 25, S47-S63. https:// phenomenon in South Africa's SMME economy', Urbani Izziv
doi.org/10.5379/urbani-izziv-en-2014-25-supplement-004

McAdam, M. \& McAdam, R., 2008, 'High tech start-ups in University Science Park incubators: The relationship between the start-up's lifecycle progression and use of the incubator's resources', Technovation 28(5), 277-290. https://doi. org/10.1016/j.technovation.2007.07.012

McDonald-Junor, D., Rossiter, W. \& Smith, D., 2018, 'From commercialising intellectual property to facilitating open innovation: The evolution of UK biotechnology incubators', $R$ \& $D$ management conference, R\&Designing Innovation: Transformational Challenges for Organizations and Society, Milan, Italy, June 30July 04, 2018, pp. 1-12.

Meru, A.K. \& Struwig, M., 2015, 'Business-incubation process and business development in Kenya: Challenges and recommendations', Journal of Entrepreneurship and Innovation in Emerging Economies 1(1), 1-17. https://doi. org/10.1177/2393957514554982

Miranda, M.G. \& Borges, R., 2019, 'Technology-based business incubators: An exploratory analysis of intra-organizational social networks', Innovation \& Management Review 16(1), 36-54. https://doi.org/10.1108/INMR-04-2018-0017

Mohamad, M. \& Chin, O., 2019, 'Business networking and sustainability of small rural business: Mediating effects of entrepreneurial orientation', Management Science Letters 9(4), 595-606. https://doi.org/10.5267/j.msl.2019.1.003

Moreira, A.C., Marta, F.S. \& Carvalho, M.F.S., 2012, 'Incubation of new ideas: Extending incubation models to less-favored regions', in T. Burger-Helmchen (ed.), Entrepreneurship, creativity and innovative business models, pp. 41-58, Instituto Superior da Maia Portugal.

Mostert, W., Niemann, W. \& Kotze, T., 2017, 'Supply chain integration in the product return process: A study of consumer electronics retailers', Acta Commercii Independent Research Journal in the Management Sciences 17(1), 1-16. https:// doi.org/10.4102/ac.v17i1.487

Mrkajic, B., 2017, 'Business incubation models and institutionally void environments', Technovation 68, 44-55. https://doi.org/10.1016/j.technovation.2017.09.001

Mthombeni, T.F., 2019, 'Vegetation classification of the Witsand Nature Reserve, Northern Cape Province, South Africa', Doctoral dissertation, University of the Free State.

Muñoz, P. \& Cohen, B., 2018, 'A compass for navigating sharing economy business models', California Management Review 61(1), 114-147. https://doi. org/10.1177/0008125618795490

Nair, S. \& Blomquist, T., 2018, 'The temporal dimensions of business incubation: A value-creation perspective', The International Journal of Entrepreneurship and Innovation 1-22. https://doi.org/10.1177/1465750318817970

Nair, S. \& Blomquist, T., 2019, 'Failure prevention and management in business incubation: Practices towards a scalable business model', Technology Analysis \& Strategic Management 31(3), 266-278. https://doi.org/10.1080/09537325.2018.1495325

Navarro, L., 2018, 'Entrepreneurship policy and firm performance Chile's CORFO Seed Capital Program', Estudios de Economía 45(2), 301-316. https://doi.org/10.4067/ S0718-52862018000200301

Nicolopoulou, K., Karataş-Özkan, M., Vas, C. \& Nouman, M., 2017, 'An incubation perspective on social innovation: The London Hub-a social incubator', R\&D Management 47(3), 368-384. https://doi.org/10.1111/radm.12179

Niemann, W., Kotze, T. \& Mannya, K., 2018, 'Global sourcing risk management approaches: A study of small clothing and textile retailers in Gauteng', The Southern African Journal of Entrepreneurship and Small Business Management 10(1), 1-15. https://doi.org/10.4102/sajesbm.v10i1.141

Njau, J.M., Mwenda, L.K.M. \& Wachira, A.W., 2019a, 'Effect of infrastructural facilities support provided by business incubators on technology based new venture creation in Kenya', International Journal of Entrepreneurship and Project Management $4(1), 17-32$.

Njau, J.M., Wachira, A.W. \& Mwenda, L.K.M. 2019b, 'Effect of access to networks support provided by business incubators on technology based new venture creation in Kenya', International Journal of Entrepreneurship and Project creation in Kenya', Inter
Management 4(1), 33-50.

Nowak, M.J. \& Grantham, C.E., 2000, 'The virtual incubator: Managing human capital in the software industry', Research Policy 29(2), 125-134. https://doi.org/10.1016/ S0048-7333(99)00054-2

Olkiewicz, M., Wolniak, R., Eva-Grebski, M. \& Olkiewicz, A., 2019, ‘Comparative analysis of the impact of the Business Incubator Center on the economic sustainable development of regions in USA and Poland', Sustainability 11(1), 1-22. https://doi.org/10.3390/su11010173

Olokundun, A.M., Ogbari, M.E., Obi, J.N. \& Ufua, D.E., 2019, 'Business incubation and student idea validation: A focus on Nigerian universities', Journal of Entrepreneurship Education 22(1), 1-6.

O'Neal, T., 2005, 'Evolving a successful university-based incubator: Lessons learned from the UCF technology incubator', Engineering Management Journal 17(3), 1-15. https://doi.org/10.1080/10429247.2005.11415293

Pauwels, C., Clarysse, B., Wright, M. \& Van Hove, J., 2016, 'Understanding a new generation incubation model: The accelerator', Technovation 50(51), 13-24. https://doi.org/10.1016/j.technovation.2015.09.003

Park, K.H. \& Kim, J., 2016, 'Manual of the Korean business incubator model', Rehoboth 1-18, viewed 04 March 2019, from http://www.mekongbiz.org/wp-content/ uploads/2017/07/Incubator-Manual.pdf.

Perdomo, G., Alvarez, C. \& Urbano, D., 2014, 'Analyzing a successful Incubator Business Model: The case of Barcelona Activa', in I. Gil-Pechuán, D. Palacios-Marqués, M.P. Peris-Ortiz, E. Vendrell \& C. Ferri-Ramirez (eds.), Strategies in e-business: Positioning and social networking in online markets, pp. 39-54, Springer, Boston, MA. 
Plano Clark, V. \& Creswell, J., 2015, Understanding research: A consumer's guide, 2nd edn., Pearson Higher Education, Upper Saddle River, NJ.

Polit, D.F. \& Beck, C.T., 2012, Nursing research: Generating and assessing evidence for nursing practise, 9th edn., Lippincott Williams \& Wilkins, Philadelphia, PA.

Romein, A. \& Trip, J.J., 2017, 'The role of business incubators in the development of sustainable clusters of cultural and creative industries', International Journal of Sustainable Development Planning 12(3), 435-445. https://doi.org/10.2495/SDPV12-N3-435-445

Rosa, M.C.W., Sukoharsono, E.G. \& Saraswati, E., 2019, 'The role of venture capital on start-up business development in Indonesia', Journal of Accounting and Investment 20(1), 55-74. https://doi.org/10.18196/jai.2001108

Sagath, D., Van Burg, E., Cornelissen, J.P. \& Giannopapa, C., 2019, 'Identifying design principles for business incubation in the European space sector', Journal of Busines Venturing Insights 11(2019), 1-31. https://doi.org/10.1016/j.jbvi.2019.e00115

Sanyal, S. \& Hisam, M.W., 2018, 'The role of business incubators in creating an entrepreneurial ecosystem: A study of the Sultanate of Oman', Indian Journal of entrepreneurial ecosystem: A study of the Sultanate of Oman', Indian Journal of
Commerce and Management Studies 9(3), 60-77. https://doi.org/10.18843/ ijcms/v9i3/02

Sari, N.E., 2018, 'The influence of technological training on entrepreneurship and the success of micro, small and middle business tenant of business and technology incubator', Journal of Business Studies and Management Review 2(1), 39-46.

Smilor, R.W., 1987, 'Managing the incubator system: Critical success factors to accelerate new company development', IEEE Transactions of Engineering Management 34(3), 146-156.

Soetanto, D., 2004, Research of the role of the incubation policy in helping the growth of new technology based firms, Globelics Academy, Lisbon.

Statistics South Africa, 2016, The South I know; the home I understand, viewed 25 March 2019, from http://www.statssa.gov.za/?page_id=964.

Stefko, R. \& Steffek, V., 2017, 'A study of creative industry entrepreneurial incubation' Polish Journal of Management Studies 15(2), 250-261. https://doi.org/10.17512/ pjms.2017.15.2.23

Sudana, I.M., Apriyani, D., Supraptono, E. \& Kamis, A., 2019, 'Business incubator training management model to increase graduate competency', Benchmarking: An International Journal 26(3), 773-787. https://doi.org/10.1108/BIJ-03-2018-0069

Tello, S., Yang, Y. \& Latham, S., 2012, 'Nascent entrepreneurs access and use of network resources in a technology incubator', Journal of Small Business Management and Entrepreneurship 25(3), 375-397. https://doi.org/10.1080/082 76331.2012.10593579

Tengeh, Robertson, K. \& Choto, P., 2015, 'The relevance and challenges of business incubators that support survivalist entrepreneurs', Investment Management and Financial Innovations 12(2), 150-161.

Theodorakopoulos, N.K., Kakabadse, N. \& McGowan, C., 2014, 'What matters in business incubation? A literature review and a suggestion for situated theorising', Journal of Small Business and Enterprise Development 21(4), 602-622. https:// doi.org/10.1108/JSBED-09-2014-0152

Torun, M., 2016, Business accelerators and their differences from incubators, ResearchGate viewed 04 February 2017, from https://www.researchgate.net/publication/311810125 Business_Accelerators_and_Their_Differences_from_Incubators.

Torun, M., Peconick, L., Sobreiro, V., Kimura, H. \& Pique, J., 2018, 'Assessing busines incubation: A review on benchmarking', International Journal of Innovation Studies 2(2018), 91-100. https://doi.org/10.1016/j.ijis.2018.08.002
Tselepis, T.J., 2018, 'When clothing designers become business people: A design centred training methodology for empowerment incubation', International Journal of Fashion Design, Technology and Education 11(3), 299-309. https://doi org/10.1080/17543266.2018.1431809

Van Weele, M., Van Rijnsoever, F.J., Eveleens, C.P., Steinz, H., Van Stijn, N. \& Groen, M., 2018, 'Start-EU-up! Lessons from international incubation practices to address the challenges faced by Western European start-ups', The Journal of Technology Transfer 43(5), 1161-1189. https://doi.org/10.1007/s10961-0169538-8

Van Weele, M.A., Van Rijnsoever, F.J., Groen, M. \& Moors, E.H., 2019, 'Gimme shelter? Heterogeneous preferences for tangible and intangible resources when choosing an incubator', The Journal of Technology Transfer 3(2019), 1-32.

Verman, S., 2004, Success factors for business incubators: An empirical study of Canadian Business Incubators, Eric Sprott School of Business, Carleton University, Ottawa, ON.

Vermeulen, Y, Niemann, W. \& Kotze, T., 2016, 'Supply chain integration: A qualitative exploration of perspectives from plastic manufacturers in Gauteng', Journal of Transport and Supply Chain Management 10(1), 1-13. https://doi.org/10.4102/ tscm.v10i1.223

Von Zedtwitz, M., 2003, 'Classification and management of incubators: Aligning strategic objectives and competitive scope for new business facilitation' International Journal of Entrepreneurship and Innovation Management 3(2), 176-196. https://doi.org/10.1504/IJEIM.2003.002227

Wenner, M.D., Bollers, E., Clarke, D. \& Pasha, S., 2018, Small business survival in Guyana: Insights and implications, No. IDB-TN-01428, Inter-American Development Bank, pp. 1-43, viewed 04 March 2019, from https://publications. iadb.org/en/small-business-survival-guyana-insights-and-implications.

Wiggins, J. \& Gibson, D.V., 2003, 'Overview of US incubators and the case of the Austin Technology Incubator', International Journal of Entrepreneurship and Innovation Management 3(2), 56-66. https://doi.org/10.1504/IJEIM.2003.002218

Wolniak, R. \& Grebski, M.E., 2018, 'Comparative analysis of the level of satisfaction with the services received at the business incubators in USA and Poland-preincubation and incubation stage', Production Engineering Archives 20(2018), 38-42. https://doi.org/10.30657/pea.2018.20.08

Xiao, L. \& North, D., 2018, 'The role of technological business incubators in supporting business innovation in China: A case of regional adaptability?', Entrepreneurship \& Regional Development 30(2), 29-57. https://doi.org/10.1080/08985626.2017.13 64789

Yakubova, T.N. \& Moustoifa, S.B., 2019, 'Strategies of small enterprises development in African countries', Regional Science Inquiry 11(1), 136-142.

Young, J., 2017, A regional overview of the Northern Cape, viewed 29 March 2018 from https://www.globalafricanetwork.com/2017/07/06/company-news/aregional-overview-of-the-northern-cape/.

Yusubova, A. \& Clarysse, B., 2016, 'Success factors of business accelerators in three European cities: Paris, London, Berlin', in P.H. Phan, S.A. Mian \& W. Lamine (eds.), Technology entrepreneurship and business incubation: Theory, practice, lessons learned, pp. 35-56, Imperial College Press, London.

Zheng, J., Mi, Z., Milcheva, S., Shan, Y., Guan, D. \& Wang, S., 2019, 'Regional development and carbon emissions in China', Energy Economics 81, 25-36. https://doi.org/10.1016/j.eneco.2019.03.003 